\title{
Systematic literature review on university website quality
}

\author{
Ala' Hasan Saleh, Rasimah Che Mohd Yusoff, Nur Azaliah Abu Bakar, Roslina Ibrahim \\ Advanced Informatics Department, University Technology Malaysia, Kuala Lumpur, Malaysia
}

\begin{tabular}{l}
\hline \hline Article Info \\
\hline Article history: \\
Received Jun 20, 2021 \\
Revised Nov 15, 2021 \\
Accepted Nov 30, 2021 \\
\hline
\end{tabular}

\section{Keywords:}

Evaluation

Quality

Systematic literature review

University

Website

\begin{abstract}
Website is a necessity for organizations to enable users worldwide to access their information and gain a competitive edge over others. The diversity of websites makes assessing website quality a difficult task. The aim of this paper is to identify the issues faced in the quality evaluation of university websites, the models and the factors used for evaluating university website quality. Systematic literature review was used to identify and synthesize related scholarly research papers. Findings show that there is a lack of study on university website quality compared to business websites; website designers did not have the appropriate knowledge on the interface design; and the website quality evaluation is complex since there is no specific evaluation model. Webqual 4.0 model was used to evaluate the quality of universities' websites. From 24 studies, initially 79 quality factors were extracted. After performing comparison, filtration and memoing, six quality factors were identified: information quality, specific content, usability, web appearance, service interaction quality, and functionality. This study makes a useful contribution in developing university website quality model by extending the Webqual 4.0 model.
\end{abstract}

This is an open access article under the $\underline{C C B Y-S A}$ license.

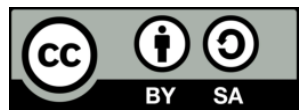

\section{Corresponding Author:}

Ala' Hasan Saleh

Advanced Informatics Department, University Technology Malaysia

Kuala Lumpur, Malaysia

Email: alaa84saleh@gmail.com

\section{INTRODUCTION}

Website is the essential interaction tool between the organization and its users in today's digital era. Having a website allows organizations to attract users worldwide to access their information and gain a competitive edge over others [1]-[3]. Institutions that have a better level of website quality will pick up higher levels of client fulfillment leading to feasible competitive advantage [4]. Websites have become more pervasive now than in the past regardless of the sector (commerce, government administrations, educations, entertainment, health care, culture, industry, financial services, and many others) [5]-[7].

Universities put enormous effort into creating a valuable website to facilitate stakeholders to access information swiftly without coming to the institutions [8]-[13]. The quality of the university's website reflects the quality of universities activities [14]. Among the information available on universities' websites include academic programs, facilities, infrastructure, activities, achievements, fields of experts, and so forth. Students have higher expectations with regards to website quality, starting from efficiency until the content [15]. Hence, quality websites can attract more users and increase their satisfaction.

Generally, the term quality encompasses the capability of a service or product in terms of meeting the needs and expectations of the consumer [16]. Quality is described by International Organization for Standardization 9000 (ISO) as "the degree to which a set of inherent characteristics of an object fulfills requirements" (ISO, 2015). Quality also implies liberation from defects which means a release from errors that call for redoing the work related to field failures, customer claims, customer dissatisfaction and others [15], [17]. 
Website quality is dependent on: to what extent it could meet the user's needs [18]. Additionally, it describes users assessment of website performing within delivering information based on its usage capability [19].

The term website quality differs from the traditional concept of quality because website quality should be perceived as a multidimensional factor that considers the users' and designers' aspects [20]. Despite experiencing a lot of weaknesses and problems in some universities websites, most universities are working hard to satisfy the international standard of website quality [21]. Evaluating the quality of a website is very important since the presence of university websites reflects the existence of a university [22]. So, it is imperative to study further on university website quality. Section 1 provides an introduction of the project. Section 2 outlines the research method. Section 3 discusses the results and finally, section 4 reports the conclusion and future works.

\section{RESEARCH METHOD}

Systematic literature reviews (SLR) is a common tool to synthesize the prevailing body of literature in a specific field [23], [24]. For this study, the SLR method was utilized to identify and synthesize related scholarly research papers [25]. SLR is defined as a method for identifying, evaluating, and synthesising the existing body of completed and recorded work created by researchers, scholars, and practitioners that is systematic, explicit, and reproducible. Contrary to the use of unstructured methods such as simple literature reviews that have a potential to be biased, SLR results are more reliable and tend to be unbiased [26], [27]. SLR comprises of three phases: review planning, review conduction, and result reporting [25] as shown in Figure 1.

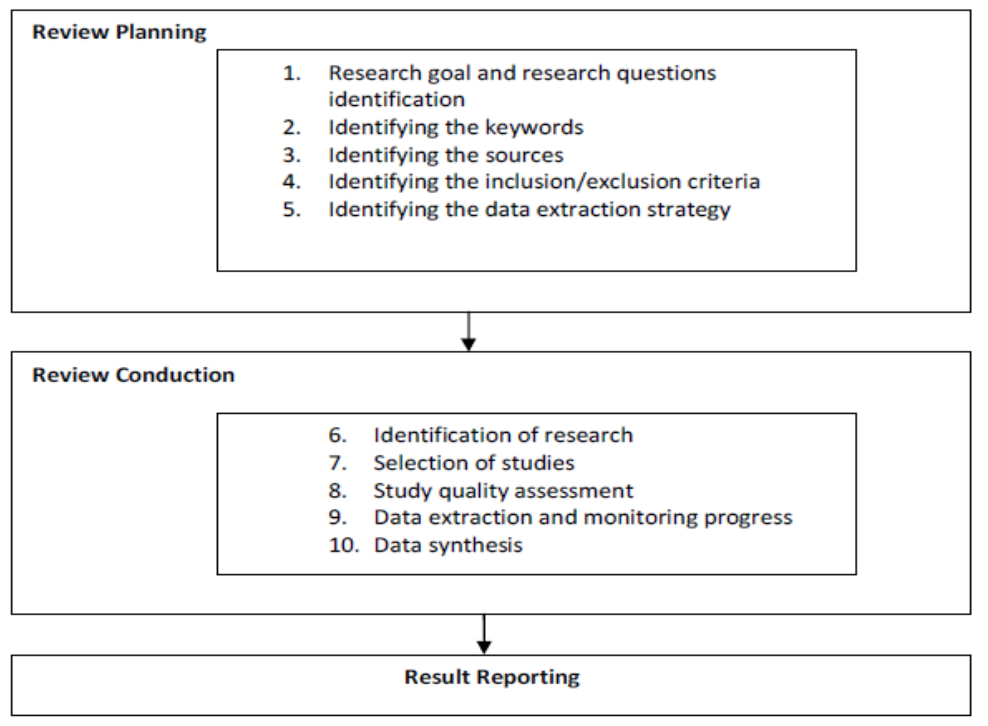

Figure 1. The systematic literature review (SLR) method [15]

\subsection{Review planning}

The most important activities during the review planning phase are definition of the research questions for this SLR and creation of the review protocol. However, all other activities should not be neglected and should be taken seriously. The results of this phase should include a clearly defined review protocol containing the purpose and the procedures of the review.

\subsubsection{Research questions}

The first step in the SLR is to determine its focus by clearly frame the questions the review seeks to answer. The questions were made by following PICO table. PICO stands for population, intervention, comparison, and outcomes [17] The formula of each item in PICO are illustrated I n Table 1.

Table 1. PICO summary

\begin{tabular}{ll}
\hline \multicolumn{1}{c}{ PICO } & \multicolumn{1}{c}{ Formula } \\
\hline Population & University websites \\
Intervention & University website quality, evaluation factors, base model \\
Comparison & N/A \\
Result & The factors and indicators to measure the quality of university website, based model, evaluation problems \\
\hline
\end{tabular}


This SLR seeks to identify answers to the following research questions:

RQ1: What are the problems for evaluating the quality of universities' websites?

RQ2: What are the models used to evaluate the quality of universities' websites?

RQ3: What are the factors and indicators being used to evaluate the quality of academic websites?

\subsubsection{Identifying the keyterms}

Based on the research questions mentioned above, the key phrase was "universities website quality evaluation." Then, the synonyms of the keyword 'evaluation' were identified which are 'assessment' and 'measurement'. The search string was formulated based on the main terms and their synonyms, and Boolean as shown: evaluation or assessment or measurement) and website and quality and (University or academic or education). The search keywords are used to find relevant studies in the paper's title, keywords and abstract.

\subsubsection{Identifying the sources}

Five databases were selected for this SLR which include Institute of Electrical and Electronics Engineers (IEEE), Springer Link, Science Direct, Emerald, and Scopus. These databases were selected as they dispense the most important and the highest impact full-text journals and conference proceedings, related to university website quality. This SLR focuses on searching for scientific databases instead of specific books or technical reports, as it assumes that the major research results in books and reports are also usually described or referenced in scientific papers.

\subsubsection{Identifying the inclusion/ exclusion criteria}

To make certain that only relevant literature is accepted into the SLR, the inclusion and exclusion criteria is used. For the exclusion criteria: papers not in the English language; only the abstract but the full text is not available; does not have factors or characteristics. While for the inclusion criteria: full-text papers; review papers, and white papers published from 2010 to the year 2020 [28].

\subsubsection{Identifying the data extraction strategy}

Data extraction is the process of capturing key characteristics of studies in structured and standardized form based on information in journal articles. The objective of this step is to design data extraction forms to accurately record the research's information that are obtained from the selected papers. After implementing the inclusion/ exclusion criteria as illustrated in the previous step, information such as citation, the context of the study, base model, and the quality factors are extracted from the selected papers in order to answer the research questions.

\subsection{Review Conducting}

\subsubsection{Identification of research}

The search process was separated into two stages which include primary and secondary search. In primary search, the papers were identified in the selected databases using the search string. In the secondary search, the selected primary studies' references were reviewed to determine any additional related studies. This process aims to ensure that the primary search phase has not missed any relevant literature. Table 2 illustrates the results of the primary studies search. After passing the primary study search through five databases, 519 papers were selected. In the secondary stage, a backward search was conducted for the selected papers of the primary studies.

Table 2. Primary search results

\begin{tabular}{cccc}
\hline Databases & Number of papers & Databases & Number of papers \\
\hline Emerald & 12 & Springer & 258 \\
IEEE & 24 & Scopus & 151 \\
Science Direct & 74 & Total & 519 \\
\hline
\end{tabular}

\subsubsection{Selection of the studies}

This step narrows down the number of documents found in the previous searching phase. To begin with, eligibility criteria was applied to determine which of the studies identified in searches are pertinent based on the paper title while all irrelevant papers were discarded. The discardment was conducted by applying filters related to the university's website quality. Furthermore, the abstract of the filtered paper was assessed followed by the introduction and the conclusion/discussion of the filtered papers. This step consisted of a more thorough selection of the documents.

After administering the first level of eligibility criteria, 13 primary studies associated with university website quality were retrieved. Using these 13 studies, a secondary search was carried out, which involved 
reviewing the references in the selected primary studies to identify relevant supplemental studies. From this secondary search phase, 17 studies were collected from the references of primary search. The final number of selected studies was 30 studies. 30 studies went through the second level of inclusion/exclusion criteria where 28 studies were included and two studies were excluded due to duplication.

\subsubsection{Study quality assessment}

This step involves assessing the quality of the selected studies in order to support the extraction of the information for synthesis and result from analysis. A quality assessment checklist was adapted from [25]. Table 3 presents the checklist that was employed for assessing the paper quality. For the quality assessment, the following scale was used: Yes=1, Partially 0.5, and $\mathrm{No}=0$ [29], it was concluded that the higher the study score, the greater the quality of the study which is concurrent with its ability to address the research question in a better way.

Table 3. Study quality assessment checklist [13]

\begin{tabular}{lc}
\hline No. & Question \\
\hline QA1 Are the aims clearly stated? & Yes/No/Partially \\
QA2 Are the methods used in each paper clearly described? & Yes/No/Partially \\
QA3 Do the objectives lead to conclusions? & Yes/No/Partially \\
QA4 Is the knowledge or understanding been extended by the research? & Yes/No/Partially \\
QA5 Is the diversity of perspective and context been explored? & Yes/No/Partially \\
QA6 Are the links between data, interpretation, and conclusions are clear? & Yes/No/Partially \\
QA7 Does the detail/ depth/ complexity of the data is conveyed? & Yes/No/Partially \\
\hline
\end{tabular}

In the next step, the total scores for each article were calculated and the percentage was determined by dividing the total score by seven. A paper with the total score greater than five or $70 \%$ will be selected for the final study. From the previous 28 papers, four papers were rejected where three papers scored 4.0 or $57 \%$ and one scored 3.5 or $50 \%$. So, there are 24 final studies selected from this SLR process. The result of quality assessment for the final selected studies is illustrated in Table 4. Figure 2 shows the overall process of this SLR process and the results for each steps.

Table 4. Result of quality assessment for final studies

\begin{tabular}{cccccccccc}
\hline Citations & QA1 & QA2 & QA3 & QA4 & Q5 & QA6 & QA7 & Total & $\%$ \\
\hline$[8]$ & 1 & 1 & 1 & 1 & 1 & 0.5 & 1 & 6.5 & 93 \\
{$[11]$} & 1 & 1 & 1 & 1 & 1 & 1 & 1 & 7 & 100 \\
{$[30]$} & 1 & 1 & 1 & 1 & 1 & 0.5 & 0.5 & 6 & 86 \\
{$[31]$} & 1 & 1 & 1 & 1 & 1 & 1 & 1 & 7 & 100 \\
{$[32]$} & 1 & 1 & 1 & 1 & 1 & 1 & 1 & 7 & 100 \\
{$[33]$} & 1 & 1 & 1 & 1 & 1 & 1 & 0.5 & 6.5 & 93 \\
{$[34]$} & 1 & 1 & 1 & 1 & 1 & 1 & 1 & 7 & 100 \\
{$[35]$} & 0.5 & 1 & 0.5 & 1 & 1 & 0.5 & 0.5 & 5 & 71 \\
{$[36]$} & 1 & 1 & 1 & 1 & 1 & 1 & 1 & 7 & 100 \\
{$[37]$} & 1 & 1 & 1 & 1 & 0 & 0.5 & 0.5 & 5 & 71 \\
{$[38]$} & 1 & 0.5 & 1 & 1 & 1 & 0.5 & 0.5 & 5.5 & 79 \\
{$[39]$} & 1 & 0.5 & 1 & 0.5 & 1 & 0.5 & 1 & 5.5 & 79 \\
{$[40]$} & 1 & 1 & 1 & 0.5 & 1 & 0.5 & 1 & 6 & 86 \\
{$[41]$} & 1 & 1 & 1 & 1 & 1 & 1 & 1 & 7 & 100 \\
{$[42]$} & 1 & 0.5 & 1 & 1 & 1 & 0.5 & 0.5 & 5.5 & 79 \\
{$[43]$} & 1 & 1 & 1 & 1 & 1 & 1 & 1 & 7 & 100 \\
{$[44]$} & 1 & 1 & 1 & 0.5 & 1 & 0.5 & 1 & 6 & 86 \\
{$[45]$} & 1 & 1 & 1 & 0.5 & 1 & 0.5 & 1 & 6 & 86 \\
{$[46]$} & 1 & 1 & 1 & 1 & 1 & 1 & 1 & 7 & 100 \\
{$[47]$} & 1 & 1 & 1 & 1 & 1 & 1 & 1 & 7 & 100 \\
{$[48]$} & 1 & 1 & 1 & 1 & 1 & 1 & 1 & 7 & 100 \\
{$[49]$} & 1 & 0.5 & 1 & 1 & 1 & 0.5 & 0.5 & 5.5 & 79 \\
{$[50]$} & 1 & 1 & 1 & 1 & 0.5 & 1 & 0.5 & 6 & 86 \\
{$[51]$} & 1 & 1 & 1 & 1 & 1 & 1 & 0.5 & 6.5 & 93 \\
\hline & & & & & & & & &
\end{tabular}

\subsubsection{Data extraction and monitoring progress}

24 studies were selected and systematically reviewed. The extracted information such as citation, the context of the study, the base model, and the quality factors have been used in the final study and synthesized to answer the research questions. The main content from the extracted information represented in the Table 5. 


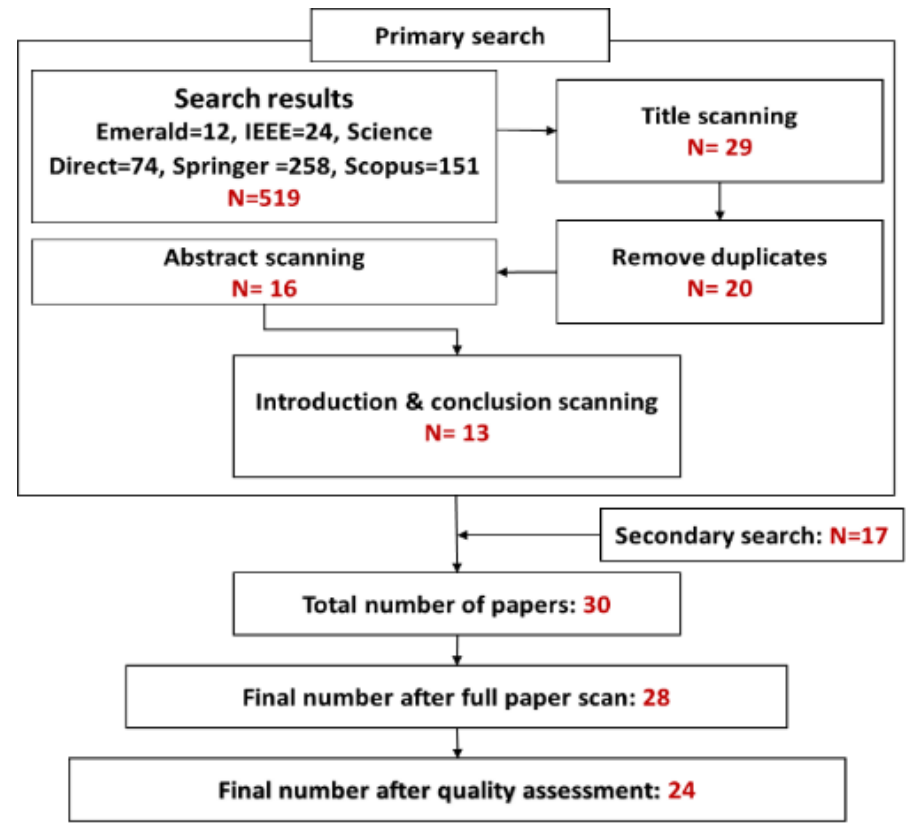

Figure 2. Overall SLR process

Table 5. Fields of studies and institutions for final papers

\begin{tabular}{lccl}
\hline ID & Citation & Field of Study & \multicolumn{1}{c}{ Institutions } \\
\hline R1 & {$[8]$} & University website & Telkom University, Indonesia \\
R2 & {$[11]$} & University website & University of Kanjuruhan Malang, Indonesia \\
R3 & {$[30]$} & Academic libraries & Nigerian academic libraries \\
R4 & {$[31]$} & University website & Nigerian University \\
R5 & {$[32]$} & University website & Iranian state university \\
R6 & {$[33]$} & Course website & National Taiwan Ocean University \\
R7 & {$[34]$} & University website & Tanzanian Public University \\
R8 & {$[35]$} & College library website & Institute of Science and Technology, China \\
R9 & {$[36]$} & University website & Delft University of Technology, Netherlands \\
R10 & {$[37]$} & University website & Institut Teknologi Sepuluh Nopember Surabaya, Indonesia \\
R11 & {$[38]$} & University website & X University, USA \\
R12 & {$[39]$} & University website & University of Bari's, Italy \\
R13 & {$[40]$} & University website & 118 Portuga universities \\
R14 & {$[41]$} & University website & Malaysian Universiti \\
R15 & {$[42]$} & University libraries & Maharaja Sayajirao University \\
R16 & {$[43]$} & University website & Kenyan University \\
R17 & {$[44]$} & Research institute & X Agency \\
R18 & {$[45]$} & University website & Jember University, Indonesia \\
R19 & {$[46]$} & Higher education services & LL-Dikti IV \\
R20 & {$[47]$} & University website & Eastern Samar State University, Philippine \\
R21 & {$[48]$} & University website & Universities in Indonesia \\
R22 & {$[49]$} & University website & Universitas Sumatera Utara, Indonesia \\
R23 & {$[50]$} & University website & Three Jordanian universities \\
R24 & {$[51]$} & Language center websites & Mulawarman University \\
\hline & \multicolumn{3}{c}{} \\
\end{tabular}

\subsubsection{Data synthesis}

The quality factors were identified from the 24 relevant research based on user perspectives. Data coding technique was used to label and organize the factors into themes. From 24 studies, 79 quality factors were extracted. Based on the similarities and differences of data codes, a constant comparison was performed. To identify the similarities, filtration was done based on explicit and implicit duplication. Explicit duplication is the clear duplication using the same code. For example, code for 'Usability' that appeared in many papers will be included once. Implicit duplication is the difference code that has the same meaning. For example, 'information quality' and 'content quality' have the same meaning. After removing duplications and applying memoing technique, six quality factors were generated as in Table 6. 


\begin{tabular}{cll}
\multicolumn{4}{c}{ Table 6. The list of universities websites quality factors } \\
\hline No. & \multicolumn{1}{c}{ Quality factors } & \multicolumn{1}{c}{ Study ID } \\
\hline 1 & Information quality & $\mathrm{R} 10, \mathrm{R} 22, \mathrm{R} 8, \mathrm{R} 3, \mathrm{R} 9, \mathrm{R} 4, \mathrm{R} 5, \mathrm{R} 11, \mathrm{R} 13, \mathrm{R} 20, \mathrm{R} 1, \mathrm{R} 14, \mathrm{R} 19, \mathrm{R} 15, \mathrm{R} 16$ \\
2 & Specific content & $\mathrm{R} 10, \mathrm{R} 8, \mathrm{R} 9$ \\
3 & Usability & $\mathrm{R} 10, \mathrm{R} 22, \mathrm{R} 8, \mathrm{R} 3, \mathrm{R} 9, \mathrm{R} 4, \mathrm{R} 5, \mathrm{R} 11, \mathrm{R} 6, \mathrm{R} 12, \mathrm{R} 13, \mathrm{R} 1, \mathrm{R} 14, \mathrm{R} 19, \mathrm{R} 15, \mathrm{R} 7, \mathrm{R} 16$ \\
4 & Web appearance & $\mathrm{R} 10, \mathrm{R} 22, \mathrm{R} 3, \mathrm{R} 9, \mathrm{R} 20, \mathrm{R} 1, \mathrm{R} 14, \mathrm{R} 19$ \\
5 & Service interaction quality & $\mathrm{R} 3, \mathrm{R} 4, \mathrm{R} 5, \mathrm{R} 11, \mathrm{R} 6, \mathrm{R} 12, \mathrm{R} 13, \mathrm{R} 1, \mathrm{R} 15, \mathrm{R} 16$ \\
6 & Functionality & $\mathrm{R} 8, \mathrm{R} 4, \mathrm{R} 6, \mathrm{R} 12, \mathrm{R} 20, \mathrm{R} 1, \mathrm{R} 14, \mathrm{R} 7$ \\
\hline
\end{tabular}

\section{RESULTS AND DISCUSSION}

In this section, we talk about how this work can be helpful for research communities. This work also leads to some possible future work areas. This research was conducted to answer three main research questions:

\subsection{To investigate the issues of evaluating the quality of universities' websites}

Table 7 presents the issues of evaluating universities' websites quality. The findings indicate that there is still a lack of study on university websites quality compared to business websites [33], [34]. From the developers aspects, some of the designers did not have the appropriate knowledge of usability engineering and user interface design which affect the quality of the websites. The most common issue is related to website evaluation aspects since website quality evaluation is complex and multidimensional and there is no specific evaluation model for university websites. The evaluation of universities' websites differs from other websites, in terms of structure and content. Besides, the factor of priorities and weights depend on the website type [11], [12], [52]-[54]. For example, user interface and atractiveness are essential factors to attract more consumers to an e-commerce website [55]. Conversely, information quality is more important for educational website [10], [56]. Moreover, there is often an overlapping among factors and sub-factors [57] which generally happens for the models inspired by software quality standards [5], [57]. For example, 'efficiency' is the main factor in ISO 9126 model, but it is a subfactor in the WebQual 4.0 model. Additionally, several website quality evaluation models are not scalable in terms of indicators [5], [58] The possibility to focus only on some quality factors or sub-factor while ignoring the others, is generally not kept into consideration [1], [59]. It is challenging to evaluate the quality of university website as various types of different indicators affect the website's design [60].

Table 7. The issues of evaluating universities websites quality

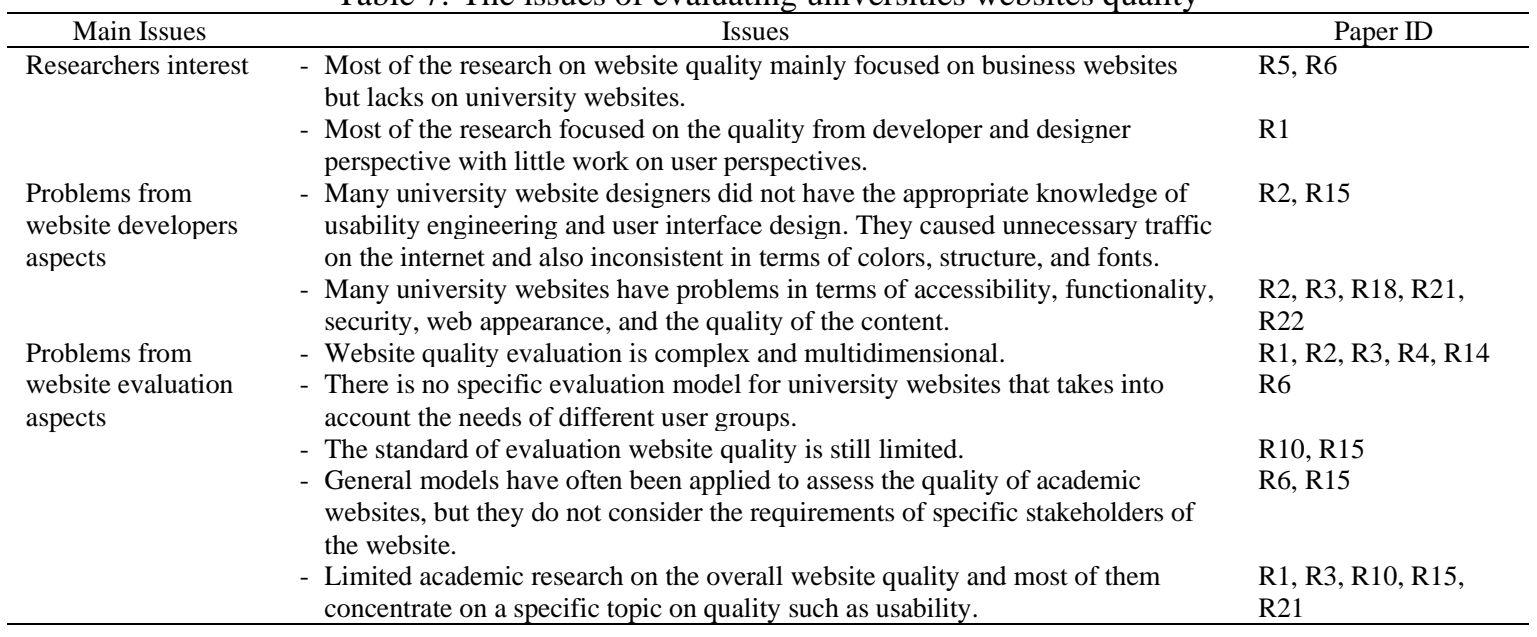

\subsection{To identify the base model or aspect for evaluating the quality of universities' websites}

Table 8 and Figure 3 illustrate the distribution of models or aspects of criteria used to evaluate the university website quality. There are 11 evaluation models were extracted from this SLR. The most frequent model used to measure the quality was WebQual 4.0 (46\%), followed by ISO/IEC 9126 (13\%).

\subsection{To investigate factors and indicators to evaluate the quality of universities' websites}

79 quality factors from 24 studies have been extracted in this SLR. After removing duplications and applying memoing technique, six quality factors were identified: Information quality, specific content, usability, web appearance, service interaction quality, and functionality. Besides the factors, this study also identified the indicators for each factors as listed in Table 9. 
Table 8 . Base model for website quality evaluation

\begin{tabular}{llll}
\hline \multicolumn{1}{c}{ Base Model } & \multicolumn{1}{c}{ Study ID } & \multicolumn{1}{c}{ Base Model } & \multicolumn{1}{c}{ Study ID } \\
\hline Aladwani's and Palvia's instrument & R1, R5 & QinUEM & R14 \\
7Loci meta-model & R15 & Usability Heuristic guidelines & R2 \\
CAWI questionnaire & R13 & WebQEM & R9 \\
Functionalities features & R3 & Zhang Mei model & R11 \\
ISO/IEC 9126 & R6, R10, R17 & WebQual 4.0 & R4, R7, R8, R16, R18, R19, \\
Performance criterias & R12 & & R20, R21, R22, R23, R24 \\
\hline
\end{tabular}

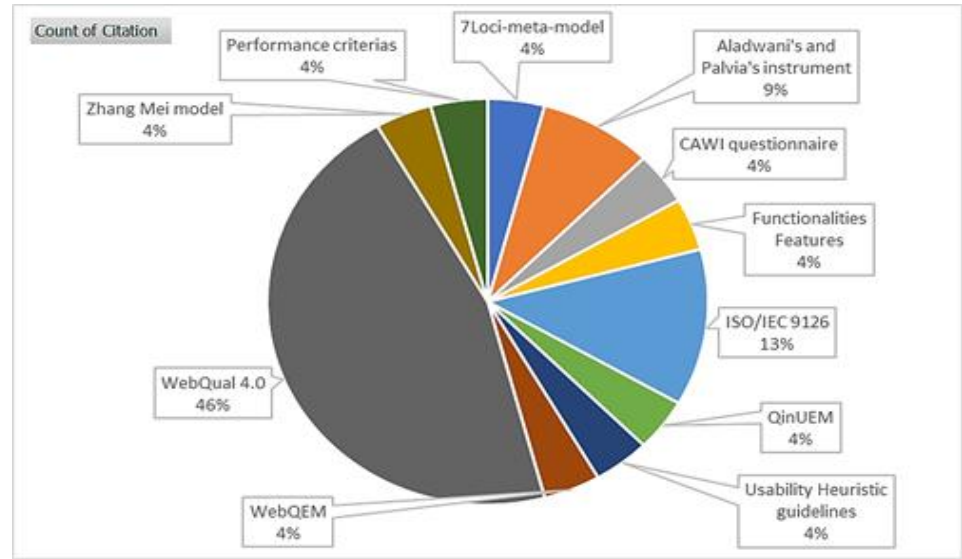

Figure 3. Base model for website quality evaluation

Table 9. List of factors and their indicators

\begin{tabular}{|c|c|c|c|}
\hline Factor & Indicators & Factor & Indicators \\
\hline Information & Usefulness & Web Appearance & Attractiveness \\
\hline \multirow{11}{*}{ Quality } & Completeness & & Changing look \\
\hline & Clarity & & Proper use of fonts \\
\hline & 4. Currency & & Proper use of colors \\
\hline & 5. Information accuracy & & Appropriate use of images \\
\hline & Information believable & & Proper use of multimedia \\
\hline & 7. Information relevant & & Style consistency \\
\hline & 8. Information detail & & Proper choice of page length \\
\hline & 9. Information uniqueness & & Good labeling \\
\hline & 10. Information broadness & & Text-only option \\
\hline & 11. Information originality & & Proper use of language \\
\hline & 12. Variety information & & Good labeling \\
\hline \multirow[t]{11}{*}{ Specific Content } & 1. Research interest \& achievement & & Text-only option \\
\hline & 2. Student portal & & Enjoyment \\
\hline & 3. Course description & & Noticeable logo \\
\hline & Timetable & & Logical structure \\
\hline & 5. Contact information & Service Interaction & Good reputation \\
\hline & 6. General information & Quality & Secure transaction \\
\hline & Brochure & & Secure information \\
\hline & 8. Admissions & & Personalization \\
\hline & 9. Academic policies & & Sense of community \\
\hline & 10. Research information & & Responsiveness \\
\hline & 11. Frequently used forms & & Trust \\
\hline \multirow[t]{16}{*}{ Usability } & 1. Easy to learn to operate & & Recoverability \\
\hline & 2. Miscellaneous features & & Availability \\
\hline & 3. Easy to navigate & & Non-deficiency \\
\hline & 4. Easy to use & & Additional services \\
\hline & 5. Competent & Functionality & Searching and retrieving \\
\hline & Creates a positive experience & & Suitability \\
\hline & 7. Use of special plug-ins & & Student-oriented domain features \\
\hline & 8. Anonymity & & 4. $\quad$ Effective \\
\hline & 9. Browser sniffing & & 5. Accessibility \\
\hline & 10. Interactivity & & Portable device compatibility \\
\hline & 11. Multi-language & & 7. Visibility features \\
\hline & 12. Page Speed & & Bookmark facility \\
\hline & 13. Links visibility & & Stability \\
\hline & 14. Alternative paths & & 10. Changeability \\
\hline & 15. User-Friendliness & & 11. Interoperability \\
\hline & & & Flexibility \\
\hline
\end{tabular}




\section{CONCLUSION}

This paper employed SLR to search for papers related to university website quality by addressing the following research questions: RQ1: What are the problems in evaluating the quality of universities' websites? RQ2: What is the base model used to evaluate the quality of universities' websites? RQ3: What are the factors and indicators being used to evaluate the quality of university websites? Regarding the issues for university website quality evaluation, a variety of evaluation criteria have been used. 24 final papers were considered eligible after the inclusion/exclusion process and quality assessment. Majority issues of university websites quality were related with website evaluation aspects since website quality evaluation is complex and multidimensional. Majority studies used the Webqual 4.0 as the base model to evaluate the universities website where information quality, usability, and service interaction quality are the factors for Webqual 4.0 model. From the final articles, 79 factors were identified to evaluate the university website quality. After removing duplications and applying memoing technique, six quality factors were identified which are information quality, specific content, usability, web appearance, service interaction quality, and functionality. These identified website quality factors extend the factors used for Webqual 4.0 by adding specific content, web appearance, and functionality as the important factors to measure university website quality. With regard to future work, the researcher is interested to validate the factors and indicators identified from this SLR with experts in order to develop the university website quality model.

\section{REFERENCES}

[1] F. Faustina and T. Balaji, "Evaluation of universities websites in Chennai city, India using analytical hierarchy process," Int. Conference on Electrical, Electronics, and Optimization Techniques, 2016, pp. 112-116, doi: 10.1109/ICEEOT.2016.7754850.

[2] N. A. Hidayah, A. Subiyakto, and F. Setyaningsih, "Combining Webqual and Importance Performance Analysis for Assessing A Government Website," 2019 7th International Conference on Cyber and IT Service Management, CITSM 2019, 2019, doi: 10.1109/CITSM47753.2019.8965408.

[3] M. Shayganmehr and G. A. Montazer, "Identifying Indexes Affecting the Quality of E-Government Websites," 2019 5th International Conference on Web Research, ICWR 2019, 2019, pp. 167-171, doi: 10.1109/ICWR.2019.8765293.

[4] E. N. Joyami and D. Salmani, "Assessing the quality of online services (website) of Tehran University Ehsan," New Trends and Issues Proceedings on Humanities and Social Sciences Volume, 2019, vol. 6, no. 7, pp. 116-129, doi: 10.18844/prosoc.v6i7.4519.

[5] D. Fogli and G. Guida, "Evaluating quality in use of corporateweb sites: An empirical investigation," ACM Transactions on the Web, vol. 12, no. 3, 2018, doi: 10.1145/3184646.

[6] H. Najadat, A. Al-badarneh, and S. Alodibat, "A review of website evaluation using web diagnostic tools and data envelopment analysis," Bulletin - British Society for Middle Eastern Studies, vol. 10, no. 1, pp. 258-265, 2021, doi: 10.11591/eei.v10i1.1755

[7] Y. Lee and J. Cho, "Web document classification using topic modeling based document ranking," International Journal of Electrical and Computer Engineering (IJECE), vol. 11, no. 3, pp. 2386-2392, 2021, doi: 10.11591/ijece.v11i3.pp2386-2392.

[8] D. D. J. Suwawi, E. Darwiyanto, and M. Rochmani, "Evaluation of academic website using ISO/IEC 9126," 2015 3rd International Conference on Information and Communication Technology, ICoICT 2015, May 2015, pp. 222-227, doi: 10.1109/ICoICT.2015.7231426.

[9] S. Owoyele, "Website as a marketing communication tool," Thesis, Business Management, Centria University of Applied Sciences, Kokkola, Finlandia, 2017.

[10] D. Pamučar, Ž. Stević, and E. K. Zavadskas, "Integration of interval rough AHP and interval rough MABAC methods for evaluating university web pages," Applied Soft Computing Journal, vol. 67, pp. 141-163, 2018, doi: 10.1016/j.asoc.2018.02.057.

[11] C. Frisdiantara, K. Qamar, Y. Ardian, and E. F. Rahman, "The effect of website quality using webqual 4.0 method on student's decision in registering at University of Kanjuruhan Malang," Proceedings of the International Conference on Industrial Engineering and Operations Management, March 2020, pp. 2057-2062.

[12] S. Kaur and S. K. Gupta, "A fuzzy-based framework for evaluation of website design quality index," International Journal on Digital Libraries, vol. 22, no. 4, 2020, doi: 10.1007/s00799-020-00292-6.

[13] H. Dewiyana, "Website Navigation Structure Library State University of Medan and State Islamic University of North Sumatra," ICEST 2018-3rd Int. Conf. of Comp., Environment, Agriculture, Social Science, Health Science, Engineering and Technology, 2018, pp. 312-316, doi: 10.5220/0010042203120316.

[14] R. Wardoyo and T. Wahyuningrum, "University website quality ranking using logarithmic fuzzy preference programming," International Journal of Electrical and Computer Engineering (IJECE), vol. 8, no. 5, pp. 3349-3358, 2018, doi: 10.11591/ijece.v8i5.pp3349-3358.

[15] K. Król and D. Zdonek, "Aggregated indices in website quality assessment," Future Internet, vol. 12, no. 4, 2020, doi: 10.3390/FI12040072.

[16] P. J. A. Nagel and W. W. Cilliers, "Customer Satisfaction: A Comprehensive Approach," International Journal of Physical Distribution \& Logistics Management, vol. 20, no. 6, pp. 2-46, Jan. 1990, doi: 10.1108/EUM0000000000366.

[17] T. Basso, R. Moraes, M. Jino, and M. Vieira, "Requirements, design and evaluation of a privacy reference architecture for web applications and services," Proc. of the 30th Annual ACM Sym. on Applied Comp. - SAC '15, 2015, pp. 1425-1432, doi: $10.1145 / 2695664.2695774$.

[18] T. Wahyuningrum and K. Mustofa, "A systematic mapping review of software quality measurement: Research trends, model, and method," International Journal of Electrical and Computer Engineering (IJECE), vol. 7, no. 5, pp. 2847-2854, 2017, doi: 10.11591/ijece.v7i5.pp2847-2854.

[19] M. S. Al-Zahrani, "Integrating IS success model with cybersecurity factors for e- government implementation in the Kingdom of Saudi the Kingdom of Saudi Arabia," International Journal of Electrical and Computer Engineering (IJECE), vol. 10, no. 5, 2020, doi: 10.11591/ijece.v10i5.pp4937-4955.

[20] T. Semerádová and P. Weinlich, "Website Quality and Shopping Behavior Quantitative and Qualitative Evidence," Springer Nature, 2020, doi: 10.1007/978-3-030-44440-2. 
[21] S. Olaleye, I. Sanusi, D. Ukpabi, and A. Okunoye, "Evaluation of Nigeria Universities Websites Quality: A Comparative Analysis," Library Philosophy and Practice (e-journal), Feb. 2018, Accessed: Nov. 19, 2019. [Online]. Available: https://digitalcommons.unl.edu/libphilprac/1717.

[22] J. S. Bhanu, D. B. K. Kamesh, and J. K. R. Sastry, "Assessing completeness of a WEB site from Quality Perspective," International Journal of Electrical and Computer Engineering (IJECE), vol. 9, no. 6, pp. 5596-5603, 2019, doi: 10.11591/ijece.v9i6.pp5596-5603.

[23] S. Kraus and S. D.-rodríguez, "The art of crafting a systematic literature review in entrepreneurship research," International Entrepreneurship and Management Journal, vol. 16, no. 3, pp. 1023-1042, 2020, doi: 10.1007/s11365-020-00635-4.

[24] M. S. Farooq, S. Riaz, A. Abid, T. Umer, and Y. Bin Zikria, "Role of IoT Technology in Agriculture : A Systematic Literature Review," Electronics, vol. 9, no. 2, p. 319 2020, doi: 10.3390/electronics9020319.

[25] B. Kitchenham and S. Charters, "Guidelines for performing systematic literature reviews in software engineering," Technical report, EBSE Technical Report EBSE, 2007.

[26] Z. Stapić, G. Antonio, E. G. López Cabot, L. de M. Ortega, and V. Strahonja, "Performing systematic literature review in software engineering," in Central European Conference on Information and Intelligent Systems, 2012, pp. 441-493.

[27] B. L. Putro and Y. Rosmansyah, "An intelligent agent model for learning group development in the digital learning environment: A systematic literature review," vol. 9, no. 3, pp. 11-14, 2020, doi: 10.11591/eei.v9i3.2009.

[28] B. Kitchenham, O. Pearl Brereton, D. Budgen, M. Turner, J. Bailey, and S. Linkman, "Systematic literature reviews in software engineering - A systematic literature review," Information and Software Technology, vol. 51, no. 1, pp. 7-15, 2009, doi: 10.1016/j.infsof.2008.09.009.

[29] A. A. L. I. M. Al-Araibi and R. C. H. E. Mohd, "A Systematic Literature Review Of Technological Factors For E-Learning Readiness In Higher Education," vol. 93, no. 2, pp. 500-521, 2016.

[30] B. E. Asogwa, C. I. Ugwu, and F. C. Ugwuanyi, "Evaluation of electronic service infrastructures and quality of e-services in Nigerian academic libraries," Electronic Library, vol. 33, no. 6, pp. 1133-1149, 2015, doi: 10.1108/EL-04-2014-0071.

[31] A. A. Machina and L. Songjiang, "Functional Evaluation Framework for Nigerian University Websites," International Journal of Computer Applications, vol. 177, no. 21, pp. 1-9, 2019, doi: 10.5120/ijca2019919610.

[32] M. G. Niazi and M. K. A. Kamran, "Evaluating Iranian state university websites using WebQEM," Electronic Library, vol. 34, no. 6, pp. 1031-1050, 2016, doi: 10.1108/EL-07-2014-0112.

[33] H.-F. Lin, "An application of fuzzy AHP for evaluating course website quality," Computers \& Education, vol. 54, no. 4, pp. 877888, 2010, doi: 10.1016/j.compedu.2009.09.017.

[34] A. S. Sife and G. E. Msoffe, "User-perceived Quality of Selected Tanzanian Public University Websites," Library Philosophy and Practice, 2013.

[35] C. Yan, "An Evaluation Method For College Library Website Based On Evolutionary Neural Network," IET International Conference on Information Science and Control Engineering, vol. 1, pp. 5-8, 2012, doi: 10.1049/cp.2012.2383.

[36] T. W. Mebrate, "A framework for evaluating academic website's quality from students' perspective," Thesis, Computer Science/Information Architecture, Delft University of Technology, Netherlands, 2010.

[37] N. A. Rakhmawati, V. Ferlyando, F. Samopa, and H. M. Astuti, "A performance evaluation for assessing registered websites," Procedia Computer Science, vol. 124, pp. 714-720, 2017, doi: 10.1016/j.procs.2017.12.209.

[38] D. Napitupulu, "Analysis of Factors Affecting the Website Quality Based on Webqual Approach (Study Case: XYZ University)," International Journal on Advanced Science Engineering and Information Technology, vol. 7, no. 3, pp. 792-798, 2017, doi: 10.17933/bpostel.2016.140105.

[39] L. Antonucci, M. Basile, C. Crocetta, V. D’Addosio, F. D. D’Ovidio, and D. Viola, "University of Bari's Website Evaluation," Data Science and Social Research : Epistemology, Methods, Technology and Applications, pp. 67-77, 2017, doi: 10.1007/978-3319-55477-8.

[40] V. S. Carlos and R. G. Rodrigues, "Web site quality evaluation in Higher Education Institutions," Procedia Technology, vol. 5, pp. 273-282, 2012, doi: 10.1016/j.protcy.2012.09.030.

[41] N. Nwasra, N. Basir, and M. F. Marhusin, "Evaluation of Malaysian universities websites based on quality in use evaluation model," International Journal on Advanced Science, Engineering and Information Technology, vol. 8, no. 4-2, pp. 1417-1422, 2018, doi: 10.18517/ijaseit.8.4-2.6828.

[42] D. Trivedi, A. Bhatt, M. Trivedi, and P. V. Patel, "Assessment of e-service quality performance of university libraries," Digital Library Perspectives, 2021, doi: 10.1108/DLP-07-2020-0072.

[43] R. O. Ojino, L. Mich, P. Ogao, and S. M. Karume, "The quality of Kenyan university websites: A study for the re-engineering of the Masinde Muliro university website," Journal of E-Learning and Knowledge Society, vol. 9, no. 3, pp. 169-176, 2013, doi: 10.20368/1971-8829/807.

[44] J. A. Kadar, D. Napitupulu, and R. K. Jati, "Analysis of factors influencing the quality of intranet website based on WebQual approach case study in agency X," Proceeding - 2017 3rd International Conference on Science in Information Technology: Theory and Application of IT for Education, Industry and Society in Big Data Era, 2017, pp. 526-532, doi: 10.1109/ICSITech.2017.8257169.

[45] B. Prasetyo, F. Adnan, and S. A. K. Wardhani, "A measurement framework for analyze the influence of service quality and website quality on user satisfaction (Case study: An IT service in Jember University)," Int. Conf. on Electrical Engineering, Computer Science and Informatics (EECSI), vol. 2018, no. 2000, pp. 56-61, 2018, doi: 10.1109/EECSI.2018.8752845.

[46] R. R. Rerung, M. Fauzan, and H. Hermawan, "Website Quality Measurement of Higher Education Services Institution Region IV Using Webqual 4.0 Method," International Journal of Advances in Data and Information Systems, vol. 1, no. 2, pp. 89-102, 2020, doi: 10.25008/ijadis.v1i2.185.

[47] J. D. G. Quiloña and S. M. Afable, "Development and evaluation of eastern samar state University-Can-avid campus website," International Journal of Innovative Technology and Exploring Engineering, vol. 8, no. 10, pp. 3057-3060, 2019, doi: 10.35940/ijitee.J95031.0881019.

[48] A. Susanto, S. N. Rahmaini, S. J. Putra, and F. Mintarsih, "Evaluating Web Quality and Its Influential Factors in Higher Education: A Comparative Study," 2019 7th International Conference on Cyber and IT Service Management, CITSM 2019, 2019, doi: 10.1109/CITSM47753.2019.8965360.

[49] K. Syahputri, I. Rizkya, I. Siregar, and O. C. Syardhi, "Analysis of website service quality with webqual 4.0 integration method," IOP Conf. Series: Materials Science and Engineering, 2021, vol. 1122, no. 1, p. 012035, doi: 10.1088/1757-899x/1122/1/012035.

[50] L. Hasan and L. Hasan, "Heuristic Evaluation of Three Jordanian University Websites Heuristic Evaluation of Three Jordanian University Websites," Informatics in Education, vol. 12, no. 2, pp. 231-251, 2016, doi: 10.15388/infedu.2013.16. 
[51] M. B. Firdaus, N. Puspitasari, E. Budiman, J. A. Widians, and N. Bayti, "Analysis of the effect of quality mulawarman university language center websites on user satisfaction using the webqual 4.0 method," Proceedings of ICAITI 2019 - 2nd International Conference on Applied Information Technology and Innovation: Exploring the Future Technology of Applied Information Technology and Innovation, 2019, pp. 126-132, doi: 10.1109/ICAITI48442.2019.8982143.

[52] J. Wątróbski, P. Ziemba, J. Jankowski, and W. Wolski, "PEQUAL - E-commerce websites quality evaluation methodology," 2016 Federated Conf. on Comp. Science and Information Systems (FedCSIS), 2016, vol. 8, pp. 1317-1327, doi: 10.15439/2016F469.

[53] H. Kotian and B. B. Meshram, "A framework for quality management of e-commerce websites," 2017 International Conference on Nascent Technologies in Engineering, ICNTE 2017 - Proceedings, 2017, doi: 10.1109/ICNTE.2017.7947975.

[54] R. Garg, R. Kumar, and S. Garg, "MADM-Based Parametric Selection and Ranking of E-Learning Websites Using Fuzzy COPRAS," IEEE Transactions on Education, pp. 1-8, 2018, doi: 10.1109/TE.2018.2814611

[55] N. A. Daud, N. I. Aminudin, F. Redzuan, N. S. Ashaari, and Z. Muda, "Lidentification of persuasive elements in islamic knowledge website using kansei engineering," Bulletin of Electrical Engineering and Informatics, vol. 8, no. 1, pp. 313-319, 2019, doi: 10.11591/eei.v8i1.1435.

[56] S. A. Olaleye, I. T. Sanusi, D. C. Ukpabi, and A. Okunoye, "Evaluation of Nigeria Universities websites quality: A comparative analysis," Library Philosophy and Practice, vol. 2018, 2018.

[57] M. Oriol, J. Marco, and X. Franch, "Quality models for web services: A systematic mapping," Information and Software Technology, vol. 56, no. 10, pp. 1167-1182, 2014, doi: 10.1016/j.infsof.2014.03.012

[58] D. Fogli and G. Guida, "A practical approach to the assessment of quality in use of corporate web sites," Journal of Systems and Software, vol. 99, pp. 52-65, 2015, doi: 10.1016/j.jss.2014.09.006.

[59] K. Kabassi, "AHP For Evaluating E-Government," International Journal of Mathematics, Game Theory, and Algebra, vol. 27, no. 2, p. 9881,2018

[60] A. Mistry and R. A. P. Rajan, "Evaluation of web applications based on UX parameters," International Journal of Electrical and Computer Engineering (IJECE), vol. 9, no. 4, pp. 2564-2570, 2019, doi: 10.11591/ijece.v9i4.pp2564-2570.

\section{BIOGRAPHIES OF AUTHORS}

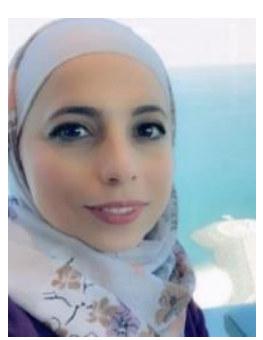

Ala' Hasan Saleh (D) SC P is a PhD candidate at Razak Faculty of Technology and Informatics, Universiti Teknologi Malaysia Kuala Lumpur, Malaysia. Her expertise in web quality, information quality. She can be contacted at email: alaa84saleh@gmail.com.

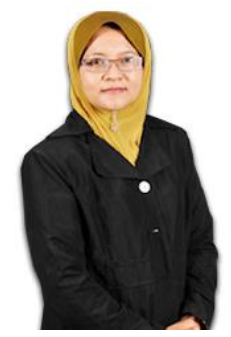

Dr. Rasimah Che Mohd Yusoff (iD SI SC P currently is a senior lecturer at Razak Faculty of Technology and Informatics, Universiti Teknologi Malaysia Kuala Lumpur, Malaysia. She received her $\mathrm{PhD}$ in Visual Informatics in 2014. Her main research areas are multimedia, mixed reality, technology acceptance, user experience (UX) and web quality. She can be contacted at email: rasimah.kl@utm.my.

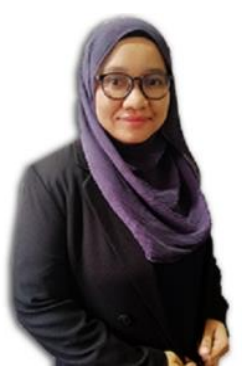

Dr. Nur Azaliah Abu Bakar (iD Bd SC P is senior lecturer at Razak Faculty of Technology and Informatics, Universiti Teknologi Malaysia. She graduated with a Bachelor (Information Technology) (Hons) in Information Systems Engineering from Multimedia University (MMU) Malaysia (2000), Masters in Information Technology from Universiti Teknologi Mara (UiTM) in 2004 and Doctor of Philosophy Information Technology (Enterprise Architecture) by Universiti Teknologi Malaysia (2017). She has 20 years' experience in ICT and has served in the Malaysian Public Sector as well as several multinational companies. Her the topics of expertise and research interests include, but are not limited to Informatics, Enterprise Architecture, Digital Government, Digital Transformation and ICT Strategic Planning. She can be contacted at email: azaliah@utm.my.

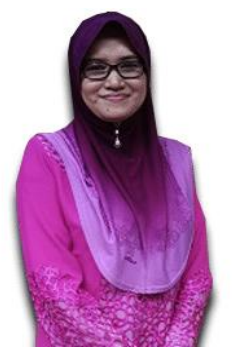

Dr. Roslina Ibrahim (iD SI SC P currently is a senior lecturer at Razak Faculty of Technology and Informatics, Universiti Teknologi Malaysia Kuala Lumpur, Malaysia. She received her PhD in Information Systems in 2014. Her main research areas are educational games, adoption/acceptance of information systems Advanced Quantitative Analysis using Structural Equation Modelling (AMOS), usability evaluation and user experience (UX). She can be contacted at email: iroslina.kl@utm.my. 